\title{
INCREASING THE WEAR RESISTANCE OF Al-Mg COMPONENTS USING THERMAL-SPRAY COATINGS
}

\author{
POVEČEVANJE ODPORNOSTI Al-Mg KOMPONENT PROTI \\ OBRABI Z UPORABO TOPLOTNO NAPRŠENIH PREVLEK
}

\author{
Raimonda Lukauskaitė, Olegas Černašėjus', Jelena Škamat², Svajus Asadauskas³, \\ Alma Ručinskiené ${ }^{3}$, Regina Kalpokaitė-Dičkuviené $\dot{4}^{4}$, Nikolaj Višniakov ${ }^{1}$ \\ ${ }^{1}$ Vilnius Gediminas Technical University, Faculty of Mechanics, 28 J. Basanavičiaus Street, 03224 Vilnius, Lithuania \\ ${ }^{2}$ Vilnius Gediminas Technical University, Scientific Institute of Thermal Insulation, 28 Linkmenu Street, 08217 Vilnius, Lithuania \\ ${ }^{3}$ Institute of Chemistry of Center for Physical Sciences and Technology, 3 Sauletelio av., 10222 Vilnius, Lithuania \\ ${ }^{4}$ Lithuanian Energy Institute, 3 Breslaujos Street, 44403 Kaunas, Lithuania \\ olegas.cernasejus@vgtu.1t
}

Prejem rokopisa - received: 2016-08-16; sprejem za objavo - accepted for publication: 2016-11-24

doi: $10.17222 / \mathrm{mit} .2016 .255$

In the present work, plasma-spray technology was applied as a means to improve the durability of Al-Mg alloy parts. $\mathrm{NiCrSiBFe}$ coatings deposited on aluminium-magnesium alloy substrates with different thickness values were studied. Before spraying, the surfaces of aluminium-magnesium alloy were modified upon applying different surface pre-treatment methods. The phase composition, microstructure, microhardness, porosity and adhesion of the deposited coatings were characterized. Ball-on-plate wear tests of the NiCrSiBFe coatings were carried out in dry and lubricated conditions, using a scanning electron microscope to characterize the worn track and the wear mechanism. The correlation of the coating porosity and the adhesion strength with the thickness of a deposited layer was determined. The results revealed that the plasma-sprayed NiCrSiBFe coatings, compared with the uncoated Al-Mg substrate, provide both a stable friction coefficient and an improved wear resistance, which is about two times better under dry sliding and about five times better under lubricated sliding.

Keywords: aluminium-magnesium substrate, NiCrSiBFe coatings, plasma spray, sliding wear, adhesion strength

V prikazanem delu je bila za izboljšanje trajnosti delov iz Al-Mg zlitin uporabljena tehnologija pršenja s plazmo. Predmet preučevanja so bile NiCrSiBFe prevleke nanesene na podlago iz aluminij-magnezijevih zlitin. Pred nanašanjem so bile površine aluminij-magnezijevih zlitin obdelane $\mathrm{z}$ različnimi postopki predpriprave površin. Določene so bile fazna sestava, mikrostruktura, mikrotrdota, poroznost in oprijem napršenih prevlek. Za določitev sledi obrabe in mehanizma je bil na $\mathrm{NiCrSiBFe}$ prevlekah izveden preizkus $\mathrm{s}$ kroglico, $\mathrm{v}$ suhih in naoljenih pogojih, in bil karakteriziran s pomočjo vrstičnega elektronskega mikroskopa. Določena je povezava med poroznostjo in jakostjo oprijema ter debelino nanešenega sloja. Rezultati so pokazali, da plazemsko napršene $\mathrm{NiCrSiBFe}$ prevleke v primerjavi z Al-Mg zlitino brez prevlek, omogočajo stabilen koeficient trenja in izboljšujejo odpornost, ki je dvakrat boljša pri drsenju po suhi podlagi, in petkrat boljša pri drsenju po naoljeni podlagi.

Ključne besede: aluminij-magnezijeva podlaga, $\mathrm{NiCrSiBFe}$ prevleke, pršenje s plazmo, drsna obraba, trdnost oprijema

\section{INTRODUCTION}

Aluminium and its alloys are used in almost all the industrial fields including civil engineering, aeronautics, transport, mechanical engineering, equipment, electric engineering, electronics, etc. However, a low melting point and hardness of aluminium parts restrain their wider applications under elevated temperatures, frictional working conditions and wear of various types. ${ }^{1,2}$ Covering aluminium items with strengthening coatings is probably one of the most hopeful ways to reduce their wear loss, minimize friction and to extend their service life.

Plasma spraying, being a very flexible process in terms of component geometry, coating materials and properties of the layer composite material achieved, look promising for aluminum parts. Due to the variety of coating materials that can be applied (including metals, ceramics and cermets), the properties of plasma-sprayed coatings may cover a wide range of applications. It was shown in a number of works ${ }^{3-9}$ that the wear conditions of aluminium parts may be significantly improved with the use of protective coatings manufactured of cast iron, Fe-based alloys, Al-based alloys and their mixtures with hard particles $\left(\mathrm{B}_{4} \mathrm{C}, \mathrm{SiC}\right)$. There are also positive results reported on composite coatings containing oxides of rare metals ${ }^{10,11}$ and duplex thermal-barrier coating. ${ }^{12}$

With respect to aluminium parts, the application of Ni-based coatings is of particular interest as well. It is known that nickel is tough and ductile due to the facecentred cubic lattice structure, existing up to the melting point; nickel has a good resistance to corrosion in many environments and shows an extensive solid solubility with many alloying elements, which, together with nickel, can form precipitate and dispersoid particles as well as unique intermetallic phases. ${ }^{13}$ A change in a spraying-powder chemical composition enables variations in the final properties of Ni-based coatings in a wide range from soft $(\sim 300 \mathrm{HV})$ antifriction coatings with an excellent resistance to corrosion and oxidation to 
hard $(\sim 780 \mathrm{HV})$ coatings with a good wear and erosion resistance. Therefore, the Ni-based coating is widely used for a multifunctional protection of the parts under various working conditions. ${ }^{14,15} \mathrm{NiCrSiBFe}$ coatings are widely applied due to their excellent wear resistance at low and moderated temperatures. Chromium forms hard phases and improves the mechanical and wear properties of a coating. ${ }^{15,16}$ Boron reduces the melting point of an alloy and makes the deposition process easier; together with silicon, it also acts as a deoxidizer; both of these elements participate in the formation of hard precipitations. ${ }^{16,17}$ When an alloy contains a particular amount of alloying elements (C, Cr, Si, B and others), the coating formed may reach high hardness; at the same time, it remains ductile enough to prevent the coating crumbling and the propagation of cracks. Nowadays, such coatings are widely used for the protection of steel parts from corrosion, high-temperature oxidation and wear of various kinds. ${ }^{15}$ It is possible that such coatings may also be effective in the improvement of the frictional and wear conditions of aluminium alloys parts.

The friction and wear performance of coated parts is mainly determined by the properties of the coating. As is known, the wear loss and friction coefficient are two main indicators used to evaluate the wear conditions of the parts under a sliding contact; however, they are influenced, besides other factors, by a number of exterior elements such as lubrication, humidity, temperature, etc. ${ }^{18}$ This makes it difficult to use numerical modelling for predicting the tribological performance of an applied system. The present study was developed in order to evaluate the efficiency of the $\mathrm{NiCrSiBFe}$ plasma-sprayed coatings used for the improvement of the aluminium-alloy-part performance under sliding wear conditions. For this purpose, the properties of the $\mathrm{NiCrSiBFe}$ coatings deposited on aluminium-magnesium alloy substrates were characterized and compared with those of the uncoated substrate.

\section{EXPERIMENTAL PART}

A self-fluxing Ni-based alloy powder (with a chemical composition, in mass fractions $(w / \%)$ of: $\sim 12 \% \mathrm{Cr}$, $\sim 4 \% \mathrm{Si}, \sim 2.5 \% \mathrm{~B}$, max. $2 \% \mathrm{Fe}, \sim 0.5 \% \mathrm{C}, \mathrm{Ni}-$ balance) was deposited on a hot-rolled AW 5754 aluminium alloy substrate $(140 \times 20 \times 4 \mathrm{~mm})$ with the plasma-spray technique. Two different pre-treatment techniques were employed to prepare the surfaces of the specimens prior to spraying: sandblasting and its combination with chemical etching $\left(30 \% \mathrm{H}_{3} \mathrm{PO}_{4}\right)$. The designation of the specimens according to the applied surface processing and the thickness of the deposited layer are presented in Table $\mathbf{1 .}$

The parameters of plasma spraying were as follows: plasma power - $33.4 \mathrm{~kW}$, spraying distance $-90 \mathrm{~mm}$, shielding gas - argon, plasma-forming gas - nitrogen. The difference in the thickness of the coating was obtained by changing the number of spray passes. The coating thickness was evaluated from digital micrographs obtained with optical microscopy and the microhardness was obtained with cross-sectional measurements using a Vickers indenter (load - $50 \mathrm{~g})$.

Table 1: Designation of the NiCrSiBFe coatings deposited on differently prepared Al-Mg substrates

\begin{tabular}{|c|c|c|c|c|c|c|}
\hline & \multicolumn{3}{|c|}{ Series A } & \multicolumn{3}{c|}{ Series B } \\
\hline Specimen & A1 & A2 & A3 & B1 & B2 & B3 \\
\hline $\begin{array}{c}\text { Pre-treatment of the } \\
\text { substrate surface }\end{array}$ & \multicolumn{3}{|c|}{ Sandblasting } & \multicolumn{3}{c|}{$\begin{array}{c}\text { Sandblasting + etch- } \\
\text { ing 30\% } \mathrm{H}_{3} \mathrm{PO}_{4}\end{array}$} \\
\hline $\begin{array}{c}\text { Roughness of the } \\
\text { pre-treated surface } \\
/ \mu \mathrm{m}\end{array}$ & 3.91 & 3.91 & 3.91 & 3.83 & 3.83 & 3.83 \\
\hline $\begin{array}{c}\text { Thickness of the } \\
\text { deposited layer }( \pm 5) \\
/ \mu \mathrm{m}\end{array}$ & 125 & 170 & 315 & 125 & 170 & 315 \\
\hline
\end{tabular}

The microstructures of the deposited coatings were examined on the polished and etched transverse crosssections using a ZEISS EVO/MA 10 scanning electron microscope (SEM) coupled with an energy dispersive spectrometer (EDS) for an X-ray micro-analysis. The last polishing step was carried out using a diamond polishing paste with a grit size of up to $1 \mu \mathrm{m}$. A $50 \mathrm{~mL} \mathrm{HCl}$ $/ 1.25 \mathrm{~mL} \mathrm{H}_{2} \mathrm{O}_{2}$ solution was used for the etching. A qualitative phase analysis of the obtained coatings was performed using the data measured on a Bruker D8 Advance $\mathrm{X}$-ray diffractometer with $K_{\alpha}(\mathrm{Cu})$ radiation in steps of $\Delta 2 \theta-0.02^{\circ}$ and the exposure time per step of $0.058 \mathrm{~s}$.

The determination of the porosity of the sprayed $\mathrm{NiCrSiBFe}$ coatings was performed on the polished transverse cross-sections using an optical NICON ECLIPSE MA200 microscope and image-analysing software "Scion Image". The last polishing step was carried out using a diamond polishing paste with a grit size of up to $1 \mu \mathrm{m}$. A $500 \times$ magnification was used. The porosity was estimated on three specimens for each set and the average was presented.

The adhesion strength was measured using a "PosiTest" pull-off tester and epoxy glue (Araldite ${ }^{\circledR}$ 2011). The abruption along the interface between the substrate and the coating was observed on all the tested samples. The average of the three individual measurements is presented in this paper.

For the evaluation of the surface wear resistance, a pin-on-disc-type tribometer (CSM Instruments) was configured into a linear reciprocal ball-on-plate regime and used under the following conditions: the total sliding distance of $40 \mathrm{~m}$, a speed of $2 \mathrm{~cm} / \mathrm{s}$, a chamber temperature of $25{ }^{\circ} \mathrm{C}$ and $50 \%$ relative humidity. A specimen tested was fixed as a plate onto the bottom and the ball, made of $100 \mathrm{Cr} 6$ steel $(\varnothing=6 \mathrm{~mm})$, was applied from the top under either dry or lubricated sliding conditions. The normal load applied on the sample was $10 \mathrm{~N}$ and a sliding amplitude of $4 \mathrm{~mm}$ was employed for the reciprocal motion. Lubricated sliding was obtained by dropping 
1-2 $\mathrm{ml}$ of Elfa oil (synthetic, 5W-30, API:SL/C). The test was performed according to the ASTM G-133 standard. The friction coefficient was recorded at a rate of 50 times per second and its average was calculated on the basis of the readings from the central $80 \%$ segment of the reciprocal motion, excluding both edges. The wear resistance was calculated with the weight residual method. The mass loss of the specimens tested was measured after the completion of every cycle of the experiment with an electronic balance KERN with a $0.001 \mathrm{~g}$ accuracy. The volume loss, coating density, wear rate and resistance were calculated using the procedure described in ${ }^{19}$. The coefficient of friction was calculated using software package InstrumX.

\section{RESULTS AND DISCUSSION}

An X-ray diffraction analysis of the coating deposited on the Al-Mg alloy substrate was performed and the results are presented in Figure 1. According to the XRD data, the NiCrSiBFe coating with a high probability consists mainly of the nickel-chromium-iron solid solution $\mathrm{Ni}_{0.73} \mathrm{Cr}_{0.18} \mathrm{Fe}_{0.09}$, iron boride $\mathrm{Fe}_{3} \mathrm{~B}$ and boron silicide $\mathrm{B}(\mathrm{Fe}, \mathrm{Si})_{3}$. In the region of $2 \Theta=40-50$, there were also reflections attributable to other phases such as nickel-silicon boride $\mathrm{Ni}_{6} \mathrm{Si}_{2} \mathrm{~B}$, chromium or iron carbide $(\mathrm{Cr}$, $\mathrm{Fe})_{23} \mathrm{C}_{6}$, carbon-iron-silicon solid solution $\mathrm{C}-\mathrm{Fe}-\mathrm{Si}$ and chromium silicide $\mathrm{Cr}_{3} \mathrm{Si}$. A comparison of related publications ${ }^{19-21}$ shows that such a phase composition is typical for the $\mathrm{NiCrSiBFe}$ coating produced of powders with similar compositions.

The microstructure of the obtained coating and the results of the EDS analysis are provided in Figure 2 and Table 2, respectively. At least three areas of different elemental compositions can be seen in the micrograph. The nickel-rich white area, denoted in Figure 2 as A and containing $\sim 16 \%$ of chromium along with some amount of iron, is most likely the nickel-chromium-iron solid solution detected also with XRD $\left(\mathrm{Ni}_{0.73} \mathrm{Cr}_{0.18} \mathrm{Fe}_{0.09}\right)$. Darker,

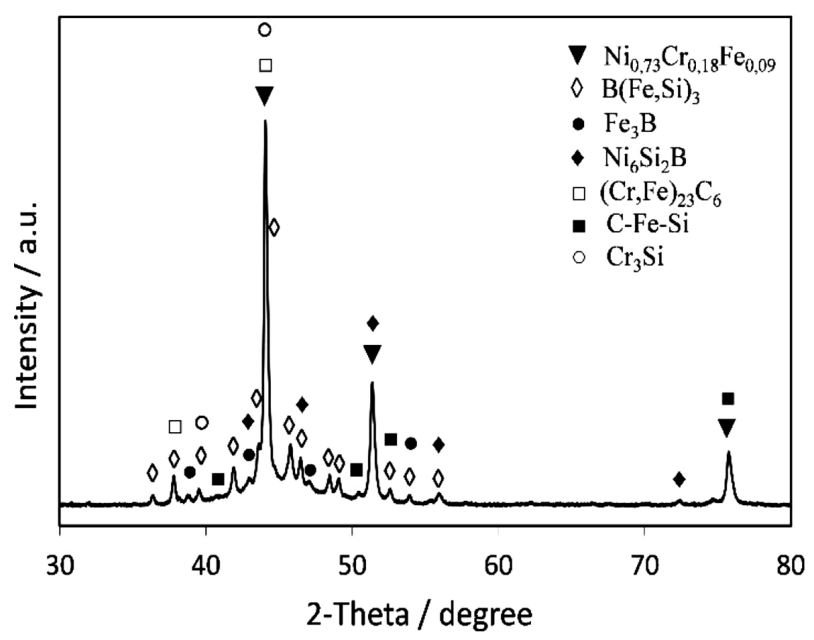

Figure 1: XRD pattern of the $\mathrm{NiCrSiBFe}$ coating obtained on the A1 specimen coloured, coarser inclusion $\mathrm{B}$ and dispersive precipitates in the $\mathrm{C}$ area indicate a presence of the elements with a lighter atomic weight, such as carbon and/or boron. Area $\mathrm{B}$ shows a higher chromium content. This, along with the XRD results, allows us to assume that in the $\mathrm{B}$ area and similar areas there may be chromium carbides and/or borides. In area $\mathrm{C}$, where many fine, dark, dispersive inclusions, incorporated in the nickel-based matrix can be seen, the highest nickel content was detected. Spatial resolution of the X-ray analysis exceeds the size of individual inclusions.

Table 2: Chemical compositions based on EDS of the areas denoted in Figure $2(w / \%)$

\begin{tabular}{|c|c|c|c|c|}
\hline Area & $\mathrm{Si}-K$ & $\mathrm{Cr}-K$ & $\mathrm{Fe}-K$ & $\mathrm{Ni}-K$ \\
\hline $\mathrm{A}$ & 4.09 & 15.54 & 2.61 & 77.77 \\
\hline $\mathrm{B}$ & 2.31 & 46.93 & 2.48 & 48.28 \\
\hline $\mathrm{C}$ & 4.69 & 9.05 & 2.30 & 83.95 \\
\hline
\end{tabular}

Therefore, the chemical compositions listed in Table 2 for the $\mathrm{C}$ area, are the results of two phases - the solid solution (A) and the dark dispersive inclusions (C). Taking into account the increased nickel content and based on the XRD data (Figure 1) along with the results reported in references, ${ }^{19-21}$ it was assumed that in the $\mathrm{C}$ area there are phases of $\mathrm{Ni}$ borides and/or silicides (such as the one obtained with XRD $-\mathrm{Ni}_{6} \mathrm{Si}_{2} \mathrm{~B}$ ) dispersed in the $\mathrm{Ni}-\mathrm{Cr}-\mathrm{Fe}$ solid solution. Other phases identified in the coating with the XRD analysis (such as iron borides or chromium silicides) are most likely also in the form of dispersive precipitates, which is typical for such compounds.

The microstructural analysis of the deposited layers with various thickness values formed on differently pre-treated substrates did not show significant differences in the coating morphology. Thus, the plasma-spray technique, employed for the coating deposition in this work, formed low-porous layers, consisting of nickelbased matrix with many incorporated hard precipitations, where chromium together with carbon participates in the formation of carbide phases, boron and silicon form

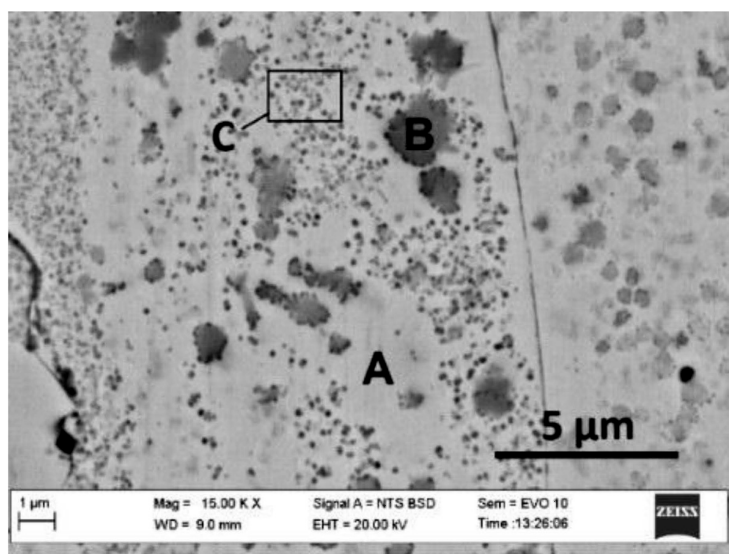

Figure 2: Microstructure of the coating 
nanosized nickel borides and/or silicides and provide dispersion strengthening of the solid solution. It all results in a high coating microchardness, which, according to the Vickers measurements performed, varies between 674 and $831 \mathrm{HV}$. Such microhardness values are in good agreement with the results reported in other publications, ${ }^{19,22,23}$ which show that the microhardness of $\mathrm{NiCrSiBFe}$ coatings can vary from 611 to $823 \mathrm{HV}^{19,22}$ when sprayed with the plasma method, and can ranged from 394 to $973 \mathrm{HV}^{23}$ when the plasma-transferred arc method is used.

The average values of the coating porosity, calculated as the ratio of the total pore area and the analyzed surface area, along with the values of adhesion determined, are presented in Figure 3. A significant increase in the porosity was observed with the increase in the coating thickness. Such a tendency is related to the gas evolution from the liquid phase during the coating crystallization and is common for thermal-spray coatings. ${ }^{24}$ The lowest porosity, determined for the coatings with the minimum thickness (A1 and B1), is $0.8 \%$ and $1.1 \%$, respectively; the highest porosity determined does not exceed $4.5 \%$. The influence of the substrate-surface pre-treatment on the porosity of the coating was not observed.

The bonding of the coating to the substrate may be realized through various mechanisms and their combinations where mechanical interlocking (anchoring) is usually dominant. Beside other factors, the condition of the substrate surface plays an important role. Mechanical roughening of the substrate removes contaminated oxidized surface layer and, due to formed surface irregularities, increases the real surface area and the probability of mechanical splats' interlocking. Here, a sandblasted surface having the average roughness $\mathrm{Ra}$ of $3.91 \mu \mathrm{m}$ provided a $13.5 \mathrm{MPa}$ adhesion strength when the thickness of the deposited layer was $120 \mu \mathrm{m}$.

Additional surface etching with orthophosphoric acid resulted in a slight roughness decrease $(3.83 \mu \mathrm{m})$ due to a partial dissolving of sharp surface irregularities. The average adhesion value obtained (14.3 $\mathrm{MPa})$ does not

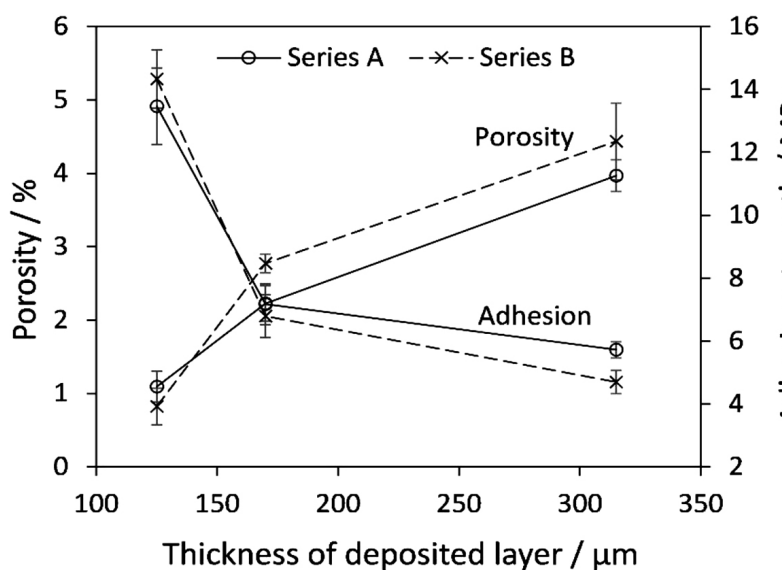

Figure 3: Porosity and adhesion of deposited coatings in dependence of their thickness

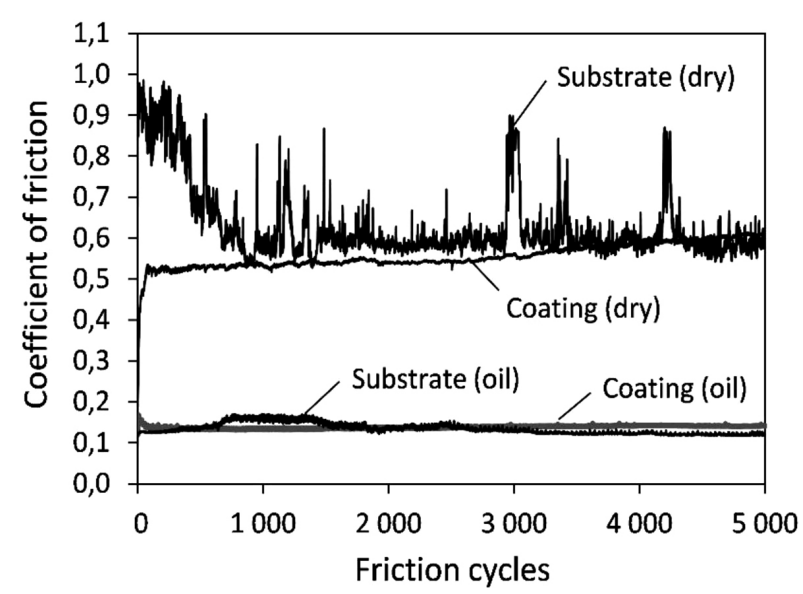

Figure 4: Friction curves

differ significantly from that of the sandblasted sample: the difference measured is in the range of the standard deviation. The adhesion bonding dramatically decreased with the increase in the coating thickness, indicating the domination of the residual-stress factor in the coating failure for thicker layers. Thus, for the sandblasted samples, the coating thickness increased by 1.36 and 2.52 times led to an adhesion decrease by 1.9 and 2.4 times, respectively. Very similar results were obtained for the samples of series B.

Tribological tests under dry and lubricated conditions were performed for all the investigated samples and the results are presented in Table 3, Figures 4 and 5. No significant difference in the friction behaviour and wear loss was observed for the coatings of different series and thickness values. Under dry conditions, the values of the friction coefficient of the A1-A3 specimen coatings
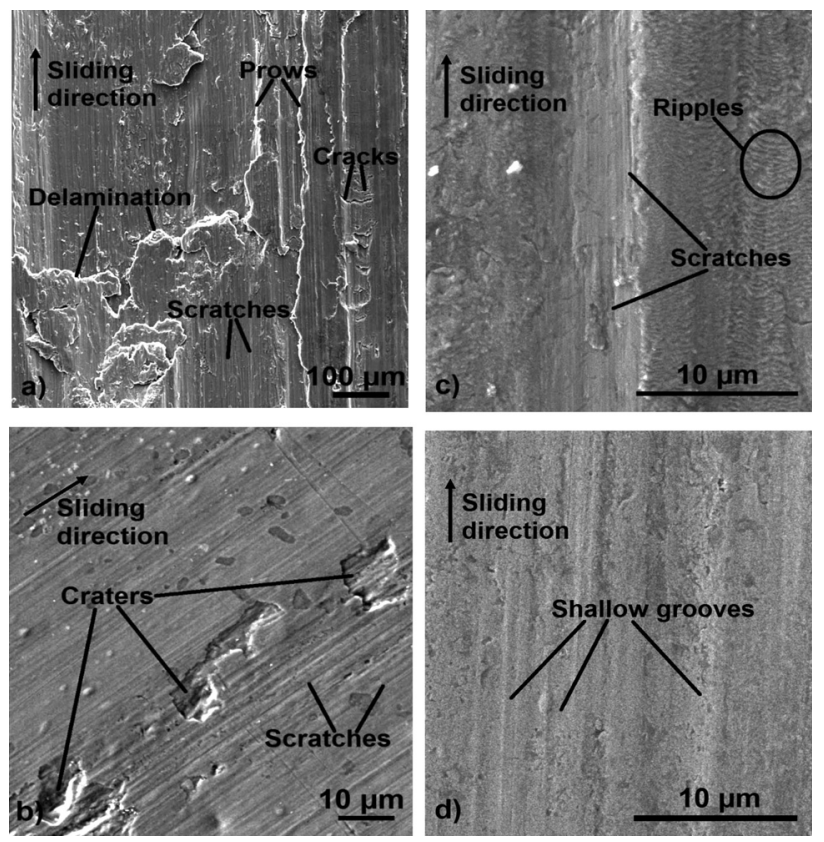

Figure 5: Wear tracks after a ball-on-plate test on the substrate: a) under dry condition, b) in oil and coating, c) under dry condition, d) in oil 
ranged from 0.57 to 0.64 and for the B1-B3 specimen coatings, they ranged from 0.56 to 0.63 , which are typical values for metallic contacts in the case of dry sliding conditions. For the Al-Mg substrate, the average friction coefficient of 0.60 was determined under dry sliding. As it was expected, the friction of both the substrate and the coating was reduced dramatically under lubrication. A stable friction-coefficient value of about 0.14 was estimated for the coatings, while for the substrate, the value varied between 0.12 and 0.17 . As can be clearly seen from the typical friction curves presented in Figure 4, the plasma-sprayed $\mathrm{NiCrSiBFe}$ coating provides a more steady friction behaviour and a stable friction coefficient compared with the Al-Mg substrate, especially during dry sliding.

Table 3: Results of the wear test

\begin{tabular}{|c|c|c|c|}
\hline & $\begin{array}{c}\text { Volume loss / } \\
\mathrm{mm}^{3}\end{array}$ & $\begin{array}{c}\text { Wear rate / } \\
\mathrm{mm}^{3} / \mathrm{m}\end{array}$ & $\begin{array}{c}\text { Wear resis- } \\
\text { tance } / \mathrm{m}^{3} \mathrm{~mm}^{3}\end{array}$ \\
\hline Substrate (dry) & 0.4978 & 0.0124 & 80.35 \\
\hline Coating (dry) & 0.2489 & 0.0062 & 160.71 \\
\hline Substrate (oil) & 0.0610 & 0.0015 & 655.74 \\
\hline Coating (oil) & 0.0124 & 0.0003 & 3225.81 \\
\hline
\end{tabular}

The cracks and fragmentation of the surface layer and its delamination along with more or less deep scratches, observed on the worn surface of the substrate after the dry-sliding test (Figure 5a), testify to the prevalence of delamination and abrasive-wear mechanisms. The presence of the longitudinal prows and cracks, transverse to the sliding direction, shows that the plastic deformation along with the adhesive wear take place during dry sliding. The delamination of coarse debris mainly causes the significant mass loss and the fluctuation of friction that is clearly observed from the presented friction curve. Lubricated sliding of the Al-Mg substrate is characterized by a worn surface, containing mainly craters and scratches along the sliding direction (Figure 5b), indicating abrasion and delamination as the predominant wear mechanisms.

Significantly fewer damage signs were observed on the worn surfaces of the coatings. Here, typical wear traces after dry sliding (Figure 5c) were shallow abrasive scratches and fine transverse ripples, most likely attributable to the excessive traction due to surface heating during dry sliding. Under the lubrication, the coating surface was damaged minimally: shallow grooves were mainly observed, indicating that a slight surface abrasion due to the asperities on the counter-body may be the dominant wear mechanism (Figure 5d). The estimated wear parameters presented in Table $\mathbf{3}$ show that, under dry sliding, the wear loss of the Al-Mg substrate is $\sim 2$ times bigger, compared to the much harder $\mathrm{NiCrSiBFe}$ coating. The lubricating oil film significantly reduces the wear loss of both the substrate ( $>8$ times) and the coating ( 20 times) and, under the lubrication, the sliding wear resistance of a coated surface is $\sim 5$ times better, compared to the uncoated substrate.

\section{CONCLUSION}

The plasma-spray technique, employed in this work, allows the formation of a protective low-porous $\mathrm{NiCrSiBFe}$ layer on an $\mathrm{Al}-\mathrm{Mg}$ substrate; hard inclusions and dispersion strengthening of the solid solution provide a high coating microhardness varying between $\sim 670$ and $\sim 830 \mathrm{HV}$.

Both the mechanical substrate pre-treatment and its combination with chemical etching, conventionally used for the aluminium-component preparation, fail to provide a satisfactory coating adhesion, particularly, when the coating thickness is increased; this indicates that further development of the pre-treatment techniques for aluminium components is of great importance.

A plasma-sprayed $\mathrm{NiCrSiBFe}$ coating provides a more steady friction behaviour and a stable friction coefficient compared with the Al-Mg substrate and it significantly improves the wear conditions of the coated parts: the wear resistance of a coated surface, compared to the uncoated substrate, is $\sim 2$ times better under dry sliding and $\sim 5$ times better under lubricated sliding.

\section{REFERENCES}

${ }^{1}$ Y. Tan, L. He, X. Wang, X. Hong, W. Wang, Tribological properties and wear prediction model of TiC particles reinforced Ni-base alloy composite coatings, Transaction of Nonferrous Metals Society of China, 24 (2014) 8, 2566-2573, doi:10.1016/S1003-6326(14) 63384-7

${ }^{2}$ L. He, Y. Tan, H. Tan, C. Zhou, L. Gao, Tribological properties of nanostructured $\mathrm{Al}_{2} \mathrm{O}_{3}-40 \% \mathrm{TiO}_{2}$ multiphase ceramic particles reinforced Ni-based alloy composite coatings, Transaction of Nonferrous Metals Society of China, 23 (2013) 9, 2618-2627, doi:10.1016/ S1003-6326(13)62776-4

${ }^{3}$ S. Uozato, K. Nakata, M. Ushio, Evaluation of ferrous powder thermal spray coatings on diesel engine cylinder bores, Surface and Coatings Technology, 200 (2005) 7, 2580-2586, doi:10.1016/ j.surfcoat.2005.05.042

${ }^{4}$ S. Uozato, K. Nakata, M. Ushio, Corrosion and wear behaviors of ferrous powder thermal spray coatings on aluminum alloy, Surface and Coatings Technology, 169-170 (2003), 691-694, doi:10.1016/ S0257-8972(03)00141-5

${ }^{5}$ W. J. Kim, S. H. Ahn, H. G. Kim, J. G. Kim, I. Ozdemir, Y. Tsunekawa, Corrosion performance of plasma-sprayed cast iron coatings on aluminum alloy for automotive components, Surface and Coatings Technology, 200 (2005) 1-4, 1162-1167, doi:10.1016/j.surfcoat. 2005.02.220

${ }^{6}$ M. F. Morks, Y. Tsunekawa, N. F. Fahim, M. Okumiya, Microstructure and friction properties of plasma sprayed Al-Si alloyed cast iron coatings, Materials Chemistry and Physics, 96 (2006) 1, 170-175, doi:10.1016/j.matchemphys.2005.07.002

${ }^{7}$ K. Nakata, M. Ushio, Effect of Fe content on wear resistance of thermal-sprayed Al-17Si-XFe alloy coatings on A6063 Al alloy substrate, Surface and Coatings Technology, 169-170 (2003), 443-446, doi:10.1016/S0257-8972(03)00187-7

${ }^{8}$ O. Sarikaya, S. Anik, S. Aslanlar, S. C. Okumus, E. Celik, Al-Si/B ${ }_{4}$ C composite coatings on Al-Si substrate by plasma spray technique, Materials and Design, 28 (2007) 9, 2443-2449, doi:10.1016/ j.matdes.2006.09.007

${ }^{9}$ M. Gui, S. B. Kang, Aluminum hybrid composite coatings containing $\mathrm{SiC}$ and graphite particles by plasma spraying, Materials Letters, 51 (2001) 5, 396-401, doi:10.1016/S0167-577X(01)00327-5 


\section{MATERIALI IN TEHNOLOGIJE/MATERIALS AND TECHNOLOGY (1967-2017) - 50 LET/50 YEARS}

\section{R. LUKAUSKAITÉ et al.: INCREASING THE WEAR RESISTANCE OF Al-Mg COMPONENTS USING ...}

${ }^{10}$ L. He, Y. Tan, X. Wang, T. Xu, X. Hong, Microstructure and wear properties of $\mathrm{Al}_{2} \mathrm{O}_{3}-\mathrm{CeO}_{2} / \mathrm{Ni}$-base alloy composite coatings on aluminum alloys by plasma spray, Applied Surface Science, 314 (2014), 760-767, doi:10.1016/j.apsusc.2014.07.047

${ }^{11}$ L. He, Y. Tan, H. Tan, Y. Tu, Z. Zhang, Microstructure and tribological properties of $\mathrm{WC}-\mathrm{CeO}_{2} / \mathrm{Ni}$-base alloy composite coatings, Rare Metal Materials and Engineering, 43 (2014) 4, 823-829, doi:10.1016/S1875-5372(14)60092-8

${ }^{12}$ L. Gu, X. Fan, Y. Zhao, B. Zou, Y. Wang, S. Zhao, X. Cao, Influence of ceramic thickness on residual stress and bonding strength for plasma sprayed duplex thermal barrier coating on aluminum alloy, Surface and Coatings Technology, 206 (2012) 21, 4403-4410, doi:10.1016/j.surfcoat.2012.04.070

${ }^{13}$ J. R. Davis, Nickel, Cobalt, and their Alloys, ASM Specialty Handbook, ASM International, Materials Park, USA 2000, 442, doi: $10.1361 /$ ncta2000p013

${ }^{14}$ C. Navas, R. Colaco, J. de Damborenea, R. Vilar, Abrasive wear behavior of laser clad and flame sprayed-melted NiCrBSi coatings, Surface and Coatings Technology, 200 (2006), 6854-6862, doi:10.1016/j.surfcoat.2005.10.032

${ }^{15}$ T. Gomez-del Rio, M. A. Garrido, J. E. Fernandez, M. Cadenas, J. Rodriguez, Influence of the deposition techniques on the mechanical properties and microstructure of NiCrBSi coatings, Journal of Materials Processing Technology, 204 (2008), 304-312, doi:10.1016/ j.jmatprotec.2007.11.042

${ }^{16}$ H. J. Kim, S. Y. Hwang, Ch. H. Lee, P. Juvanon, Assessment of wear performance of flame sprayed and fused Ni-based coatings, Surface and Coatings Technology, 172 (2003), 262-269, doi:10.1016/ S0257-8972(03)00348-7
${ }^{17}$ V. Stoica, R. Ahmed, T. Itsukaichi, Influence of heat-treatment on the sliding wear of thermal spray cermet coatings, Surface and Coatings Technology, 199 (2005), 7-21, doi:10.1016/j.surfcoat.2005.03.026

${ }^{18}$ K. G. Budinski, Friction, Wear and Erosion Atlas, CRC Press, London 2013, 277

${ }^{19}$ N. L. Parthasarathi, M. Duraiselvam, U. Borah, Effect of plasma spraying parameter on wear resistance of $\mathrm{NiCrBSiFe}$ plasma coatings on austenitic stainless steel at elevated temperatures at various loads, Materials and Design, 36 (2012), 141-151, doi:10.1016/ j.matdes.2011.10.051

${ }^{20}$ C. Navas, R. Vijande, J. M. Cuetos, M. R. Fernandez, J. Damborenea, Corrosion behavior of NiCrBSi plasma-sprayed coatings partially melted with laser, Surface and Coatings Technology, 201 (2006) 3-4, 776-785, doi:10.1016/j.surfcoat.2005.12.032

${ }^{21}$ D. Felgueroso, R. Vijande, J. M. Cuetos, R. Tucho, A. Hernandez, Parallel laser melted tracks: effects on the wear behavior of plasmasprayed Ni-based coatings, Wear, 264 (2008) 3-4, 257-263, doi:10.1016/j.wear.2007.03.015

${ }^{22}$ J. M. Miguel, J. M. Guilemany, S. Vizcaino, Tribological study of NiCrBSi coating obtained by different processes, Tribology International, 36 (2003), 181-187, doi:10.1016/S0301-679X(02)00144-5

${ }^{23}$ T. Liyanage, G. Fisher, A. P. Gerlich, Influence of alloy chemistry on microstructure and properties in NiCrBSi overlay coatings deposited by plasma transferred arc welding (PTAW), Surface and Coatings Technology, 205 (2010), 759-765, doi:10.1016/j.surfcoat. 2010.07.095

${ }^{24}$ J. R. Davis, Handbook of Thermal Spray Technology, ASM International, Materials Park, OH, USA, 2004, 339 